\title{
PENTINGNYA LITERASI KEUANGAN BAGI PENGELOLAAN KEUANGAN PRIBADI
}

\author{
Amanita Novi Yushita \\ Staf Pengajar Jurusan Pendidikan Akuntansi Universitas Negeri Yogyakarta \\ amanitanovi@uny.ac.id
}

\begin{abstract}
Abstrak : Pentingnya Literasi Keuangan Bagi Pengelolaan Keuangan Pribadi. Literasi keuangan merupakan kebutuhan dasar bagi setiap orang agar terhindar dari masalah keuangan. Kesulitan keuangan bukan hanya fungsi dari pendapatan semata (rendahnya pendapatan), kesulitan keuangan juga dapat muncul jika terjadi kesalahan dalam pengelolaan keuangan (miss-management) seperti kesalahan penggunaan kredit, dan tidak adanya perencanaan keuangan. Literasi keuangan (financial literacy) yang kian mendapatkan perhatian di banyak negara maju semakin menyadarkan betapa kepada kita betapa pentingnya tingkat 'melek' keuangan. Di beberapa negara, literasi keuangan bahkan sudah dicanangkan menjadi program nasional. Hasil riset secara umum menunjukkan bahwa masih terjadi tingkat literasi keuangan yang rendah di negara-negara maju dan terlebih lagi di negara-negara sedang berkembang termasuk Indonesia. Kondisi ini merupakan problem yang cukup serius mengingat literasi keuangan berpengaruh positif terhadap inklusi dan perilaku keuangan.
\end{abstract}

\begin{abstract}
The Importance of Financial Literacy for Personal Financial Management. Financial literacy is a basic need for everyone to avoid financial problems. Financial difficulties are not just a function of income itself (low income), financial difficulties can also arise if missmanagement errors such as misuse of credit, and absence of financial planning. Nowadays, developed countries are more concern about financial and this situation realize us about the importance of level of financial literacy. In some countries, financial literacy has even been declared as a national program. The results of general research indicate that there is still a low level of financial literacy in developed countries and moreover in developing countries including Indonesia. This condition is a serious problem considering the financial literacy has a positive effect on inclusion and financial behavior.
\end{abstract}

Kata kunci: literasi keuangan, pengelolaan keuangan

\section{PENDAHULUAN}

Pelaksanaan edukasi dalam meningkatkan pemahaman tentang keuangan di masyarakat sangat diperlukan. Dengan semakin pesatnya pembangunan dan pertumbuhan ekonomi, lembaga keuangan mempunyai peran yang penting dalam kehidupan di masyarakat luas. Dengan adanya berbagai lembaga keuangan yang bervariasi menjadikan tiap lembaga berupaya untuk menyalurkan berbagai produk dan jasa keuangan kepada masyarakat secara menyeluruh. Agar masyarakat luas dapat menentukan produk dan layanan jasa keuangan yang sesuai dengan kebutuhan, masyarakat harus memahami dengan benar manfaat dan risiko, mengetahui hak dan kewajiban serta 


\section{JURNAL NOMINAL / VOLUME VI NOMOR 1 / TAHUN 2017}

meyakini bahwa produk dan layanan jasa keuangan yang dipilih dapat meningkatkan kesejahteraan masyarakat.

Dengan jumlah penduduk yang cukup banyak, Indonesia harus mampu mempersiapkan diri dalam menghadapi persaingan global di era MEA. Salah satu cara dalam menyikapi keuangan adalah bagaimana individu mengontrol pengeluaran keuangan pribadinya. Ketika pengeluaran terus menerus dan tidak terbatas jumlahnya yang mengakibatkan individu sulit atau tidak mampu mengendalikankeuangan, hal ini menunjukkan bahwa individu memiliki tingkat literasi keuangan yang buruk.

Literasi keuangan sangat berkaitan dengan kesejahteraan individu. Pengetahuan keuangan dan ketrampilan dalam mengelola keuangan pribadi sangat penting dalam kehidupan sehari. Kesulitan keuangan bukan hanya fungsi dari pendapatan semata (rendahnya pendapatan). Kesulitan keuangan juga dapat muncul jika terjadi kesalahan dalam pengelolaan keuangan (missmanagement) seperti kesalahan penggunaan kredit, dan tidak adanya perencanaan keuangan. Keterbatasan finansial dapat menyebabkan stress, dan rendahnya kepercayaan diri. Adanya pengetahuan keuangan dan literasi keuangan akan membantu individu dalam mengatur perencanaan keuangan pribadi, sehingga individu tersebut bisa memaksimalkan nilai waktu uang dan keuntungan yang diperoleh oleh individu akan semakin besar dan akan meningkatkan taraf kehidupannya

Misi penting dari program literasi keuangan adalah untuk melakukan edukasi dibidang keuangan kepada masyarakat Indonesia agar dapat mengelola keuangan secara cerdas, sehingga rendahnya pengetahuan tentang industri keuangan dapat diatasi dan masyarakat tidak mudah tertipu pada produk-produk investasi yang menawarkan keuntungan tinggi dalam jangka pendek tanpa mempertimbangkan risikonya. Perlunya pemahaman masyarakat tentang produk dan layanan yang ditawarkan oleh lembaga jasa keuangan, maka program strategi nasional literasi keuangan mencanangkan tiga pilar utama. Pertama, mengedepankan program edukasi dan kampanye nasional literasi keuangan. Kedua, berbentuk penguatan infrastruktur literasi keuangan. Ketiga, berbicara tentang pengembangan produk dan layanan jasa keuangan yang terjangkau. Penerapan ketiga pilar tersebut diharapkan dapat mewujudkan masyarakat Indonesia yang memiliki tingkat literasi keuangan yang tinggi sehingga masyarakat dapat memilih dan memanfaatkan produk jasa keuangan guna meningkatkan kesejahteraan (OJK, 2013). 


\section{JURNAL NOMINAL / VOLUME VI NOMOR 1 / TAHUN 2017}

Melalui inisiatif program peningkatan tingkat literasi keuangan yang dimulai sejak tahun 2013 oleh Otoritas Jasa Keuangan (OJK), menunjukkan rendahnya tingkat melek keuangan. Berdasarkan survei yang dilakukan oleh OJK pada tahun 2013, bahwa tingkat literasi keuangan penduduk Indonesia dibagi menjadi empat bagian, yaitu: 1) Well literate (21,84\%), yakni memmiliki pengetahuan dan keyakinan tentang lembaga jasa keuangan serta produk jasa keuangan, termasuk fitur manfaat dan risiko, hak dan kewajiban terkait produk dan jasa keuangan, serta memiliki keterampilan dalam menggunakan produk dan jasa keuangan, 2) Sufficient literate $(75,69 \%)$, memiliki pengetahuan dan keyakinan tentang lembaga jasa keuangan serta produk dan jasa keuangan, termasuk fitur, manfaat dan risiko, hak dan kewajiban terkait produk dan jasa keuangan, 3) Less literate (2,06 $\%$ ), hanya memiliki pengetahuan tentang lembaga jasa keuangan, produk dan jasa keuangan, dan 4) Not literate $(0,41 \%)$, tidak memiliki pengetahuan dan keyakinan terhadap lembaga jasa keuangan serta produk dan jasa keuangan, serta tidak memiliki keterampilan dalam menggunakan produk dan jasa keuangan.

Literasi keuangan dapat diartikan sebagai pengetahuan keuangan, yang bertujuan untuk mencapai kesejahteraan (Lusari \& Mitchell, 2007). Pemahaman yang baik mengenai pengelolaan keuangan menjadi jalan keluar dari beragam masalah, termasuk mengurangi angka kemiskinan. Semakin tinggi literasi keuangan akan memberikan dampak kesejahteraan.

Pengetahuan dan pemahaman tentang keuangan pribadi dibutuhkan individu agar dapat membuat keputusan yang benar dalam keuangan, sehingga mutlak diperlukan setiap orang dapat secara optimal menggunakan instrumeninstrumen serta produk-produk keuangan yang tepat. Kurangnya pengetahuan mengenai literasi keuangan menjadi masalah serius dan menjadi tantangan besar bagi masyarakat di Indonesia. Edukasi financial adalah proses panjang yang memacu individu untuk memiliki rencana keuangan di masa depan demi mendapatkan kesejahteraan sesuai dengan pola dan gaya hidup yang dijalani (Mendari dan Kewal, 2013).

Literasi keuangan merupakan kebutuhan dasar bagi setiap orang agar terhindar dari masalah keuangan. Kesulitan keuangan dapat muncul jika terjadi kesalahan dalam pengelolaan keuangan (mismanagement). Memiliki literasi keuangan merupakan hal yang paling penting untuk mendapatkan kehidupan yang sejahtera. Dengan pengelolaan keuangan yang tepat yang ditunjang dengan literasi keuangan yang baik, maka taraf hidup masyarakat diharapkan akan 


\section{JURNAL NOMINAL / VOLUME VI NOMOR 1 / TAHUN 2017}

meningkat, karena walau bagaimanapun tingginya tingkat penghasilan seseorang tapi tanpa pengelolaan keuangan yang tepat, keamanan finansial pasti akan sulit tercapai. Kebutuhan edukasi kepada masyarakat terhadap produk-produk keuangan baik bank maupun nonbank sangat mendesak agar masyarakat tidak mudah tertipu oleh pihak-pihak yang tidak bertanggungjawab. Pentingnya literasi keuangan dalam bentuk semua aspek keuangan pribadi bukan karena untuk mempersulit dalam menggunakan uang yang mereka miliki, tetapi diharapkan individu dapat menikmati hidup dengan menggunakan sumber daya keuangan yang dimiliki dengan tepat.

Howell (1993) dalam Zahroh (2014) menyatakan bahwa pengelolaan keuangan pribadi merupakan salah satu kompetensi yang paling mendasar yang dibutuhkan oleh masyarakat modern, karena pilihan konsumen dari hari ke hari akan mempengaruhi keamanan keuangan dan standar hidup seseorang. Masalah dalam pengelolaan keuangan pribadi sering dianggap remeh, sehingga orang cenderung belajar tentang keuangan pribadi melalui proses trial and error.

Selain manfaat untuk individu dan masyarakat, literasi keuangan juga diperlukan untuk memajukan industri jasa keuangan karena masyarakat merupakan pengguna utama jasa keuangan. Literasi keuangan akan menciptakan efek berantai pada tingkat penggunaan produk dan jasa keuangan, yang kemudian dapat meningkatkan keuntungan dan mendorong lembaga keuangan untuk berinovasi dalam mengembangkan produk dan jasa keuangan yang lebih bervariasi.

Menurut Giltman (2002), manajemen keuangan pribadi merupakan seni dan ilmu mengelola sumber daya keuangan dari unit individu. Dengan demikian, manajemen keuangan pribadi mencakup dua unsur yakni pengetahuan akan keuangan dan seni dalam mengelola. Mengapa seni dalam mengelola itu menjadi sesuatu yang juga penting? Karena kegiatan mengelola (pengelolaan) membutuhkan kedisiplinan dan menentukan prioritas yang berasal dari pengontrolan diri. Pengontrolan diri akan membantu anda untuk tetap bertahan pada prinsip manajemen, yakni efesiensi dan efektifitas. Efesiensi, yakni menggunakan sumber-sumber dana secara optimal untuk pencapaian tujuan manajemen keuangan pribadi. Sedangkan efektifitas merujuk pada manajemen keuangan pribadi menuju pada tujuan yang tepat.

\section{KAJIAN PUSTAKA}

\section{Pengertian Literasi Keuangan (Financial Literacy)}

Keuangan merupakan aspek penting yang melekat dalam kehidupan masyarakat luas. Pengetahuan keuangan 


\section{JURNAL NOMINAL / VOLUME VI NOMOR 1 / TAHUN 2017}

yang dimiliki dapat membantu individu dalam menentukan keputusankeputusan dalam menentukan produkproduk finansial yang dapat mengoptimalkan keputusan keuangannya. Pengetahuan tentang keuangan menjadi sangat penting bagi individu agar tidak salah dalam membuat keputusan keuangan nantinya (Margaretha dan Pambudhi, 2015). Jika pengetahuan tentang keuangan yang mereka miliki kurang, akan mengakibatkan kerugian bagi individu tersebut, baik sebagai akibat dari adanya inflasi maupun penurunan kondisi perekonomian di dalam maupun di luar negeri. Kesalahpahaman menyebabkan banyak orang mengalami kerugian keuangan, sebagai akibat dari pengeluaran yang boros dan konsumsi, tidak bijaksana dalam penggunaan kartu kredit, dan menghitung perbedaan antara kredit konsumen dan pinjaman bank. Selain itu, kurangnya pengetahuan tentang keuangan menyebabkan seseorang sulit untuk melakukan investasi atau mengakses ke pasar keuangan.

Lusardi (2014) menyatakan bahwa literasi keuangan terdiri dari sejumlah kemampuan dan pengetahuan mengenai keuangan yang dimiliki oleh seseorang untuk mampu mengelola atau menggunakan sejumlah uang untuk meningkatkan taraf hidupnya dan bertujuan untuk mencapai kesejahteraan. Literasi keuangan sangat terkait dengan perilaku, kebiasaan dan pengaruh dari faktor eksternal. Sementara itu, Chen dan Volpe (1998) mengartikan literasi keuangan sebagai pengetahuan untuk mengelola keuangan agar bisa hidup lebih sejahtera di masa yang akan datang. Berdasarkan PISA 2012: Financial Literacy Assessment Framework (OECD INFE, 2012) dirumuskan bahwa literasi keuangan merupakan faktor yang fundamental untuk pertumbuhan kekonomi dan stabilitas keuangan. Dari sudut pandang konsumen, literasi keuangan yang baik akan memunculkan keputusan pembelanjaan yang mengedepankan kualitas. Hal ini akan berakibat pada kompetisi industri yang menjadi sehat dan kompetisi akan mengedepankan inovasi dalam barang dan jasa yang ditawarkan ke konsumen. Selain itu, dengan literasi keuangan yang baik juga bisa meminimalkan terjadinya keputusan yang slah terhadap isu ekonomi dan keuangan yang muncul. Dari sudut pandang penyedia jasa keuangan, literasi keuangan yang baik akan memberikan informasi yang memadai mengenai produk serta pemahaman risiko. Sedangkan dari sudut pandang pemerintah, dengan 
JURNAL NOMINAL / VOLUME VI NOMOR 1 / TAHUN 2017

adanya literasi keuangan yang baik pada masyarakat maka pemerintah dapat memperoleh pemasukan pajak dengan maksimal untuk pengembangan infrastruktur dan fasilitas pelayanan publik.

Literasi keuangan adalah mencakup kemampuan untuk membedakan pilihan keuangan, mambahas uang dan masalah keuangan tanpa ketidaknyamanan, merencanakan masa depan, dan menanggapi kompeten untuk peristiwa kehidupan yang mempengaruhi keputusan keuangan sehari-hari, termasuk peristiwa di ekonomi secara umum. Literasi keuangan terjadi manakala seorang individu memiliki sekumpulan keahlian dan kemampuan yang dapat memanfaatkan sumber daya yang ada untuk mencapai tujuan. Literasi keuangan membantu untuk meningkatkan kualitas pelayanan keuangan dan memberikan kontribusi terhadap pertumbuhan ekonomi dan pembangunan suatu negara. Semakin meningkatnya kompleksitas ekonomi, kebutuhan individu dan produk keuangan, individu harus memiliki literasi keuangan untuk mengatur keuangan pribadinya.

Proses belajar dapat diartikan sebagai pengetahuan individu untuk memahami sesuatu Pengetahuan yang berhubungan dengan keuangan dinamakan financial literacy. (Lusardi \& Mitchell, 2007) mendefinisikan melek keuangan sebagai pengetahuan keuangan dan kemampuan untuk mengaplikasikannya (knowledge and ability) (jurnal monetery economic). Finansial Literacy terjadi manakala seorang individu yang cakap (literate) adalah seseorang yang memiliki sekumpulan keahlian dan kemampuan yang membuat orang tersebut mampu memanfaatkan sumber daya yang ada untuk mencapai tujuan. Kecakapan (literacy) merupakan hal penting yang harus dimiliki untuk mencapai tujuantujuannya. Dengan demikian riset ini akan mengunakan definisi menurut (Chen \& Volpe, 1998) karena lebih menekankan pada kemampuan untuk memahami konsep dasar dari ilmu ekonomi dan keuangan, hingga bagaimana menerapkannya secara tepat. Selain itu juga, definisi menurut Chen dan Volpe (1998) memiliki 4 aspek yaitu pengetahuan umum, tabungan, asuransi dan investasi yang sesuai dengan pengelolaan keuangan pribadi.

$$
\begin{aligned}
& \text { Tingkat literasi keuangan } \\
& \text { keuangan dari sudut pandang }
\end{aligned}
$$




\section{JURNAL NOMINAL / VOLUME VI NOMOR 1 / TAHUN 2017}

digunakan untuk memiliki aset (seperti tanah atau rumah), pemenuhan pendidikan tinggi dan dana hari tua (pensiun) (Aribawa, 2016). Literasi finansial didefinisikan sebagai kemampuan seseorang untuk mendapatkan, memahami dan mengevaluasi informasi yang relevan untuk pengambilan keputusan dengan memahami konsekuensi finansial yang ditimbulkan (Carolynne L J Mason \& Richard M S Wilson : 2000). Keputusan yang berdasarkan informasi diakui sebagai instrumen untuk mencapai hasil yang diharapkan. Literasi keuangan hanya menjadikan seseorang mampu membuat keputusan berdasarkan informasi yang relevan. Literasi keuangan tidak menjamin bahwa keputusan yang tepat yang dibuat, karena seseorang tidak selalu mengambil keputusan berdasarkan rasional ekonomi (Carolynne L J Mason \& Richard M S Wilson : 2000).

Penelitian yang dilakukan Navickas, Tadas, dan Emilia (2013) menyatakan bahwa tanggung jawab perencanaan keuangan individu perlu dilakukan sedini mungkin, karena kesalahan pengaturan keuangan akan sangat merugikan dan sulit diperbaiki di masa yang akan datang. Hasil penelitian tersebut menunjukkan kurangnya pengetahuan keuangan yang menyebabkan rumah tangga tidak mampu mengatur keuangan dengan baik, menghabiskan sejumlah uang untuk membeli sesuatu yan gkurang diperlukan. Hal ini menyebabkan level simpanan menjadi rendah dan tingkat pengembalian investasi pun sedikit. Kesimpulan lainnya dari penelitian tersebut antara lain tingkat kesadaran yang tinggi akan pengetahuan tentang keuangan (financial literacy) membawa pengaruh positif dalam keputusan sehari-hari dan mendorong level tabungan yang lebih tinggi yang pada akhirnya meningkatkan kualitas hidup dalam jangka panjang.

Menurut Rohrke \& Robinson (2000), literasi keuangan adalah cara terbaik untuk mengajarkan konsumen tentang manfaat memiliki hubungan dengan lembaga keuangan diantaranya adalah pendanaan dan kredit, kemampuan untuk membangun keuangan yang positif. Sedangkan menurut Hailwood (2007) financial literacy akan mempengaruhi bagaimana orang menabung, meminjam, berinvestasi dan mengelola keuangan. Lebih jauh, kecakapan finansial disini juga lebih menekankan pada kemampuan untuk memahami konsep dasar dari ilmu ekonomi dan keuangan, sehingga bagaimana dapat menerapkan secara tepat. 
Literasi keuangan dibagi menjadi empat aspek yang terdiri dari pengetahuan keuangan dasar (basic financial knowledge), simpanan dan pinjaman (saving and borrowing), proteksi (insurance), dan investasi (Chen dan Volpe, 1998). Menurut MZ. Zahriyan pengetahuan keuangan dasar (basic financial knowledge) yang mencakup pengeluaran, pendapatan, aset, hutang, ekuitas, dan risiko. Pengetahuan dasar ini biasanya berhubungan dengan pengambilan keputusan dalam melakukan investasi atau pembiayaan yang bisa mempengaruhi perilaku seseorang dalam mengelola uang yang dimiliki.

Dalam hal keuangan, kecerdasan finansial ini meliputi 4 aspek yaitu bagaimana mendapatkan uang, bagaimana mengelola uang, bagaimana menyimpan uang dan bagaimana menggunakan uang. Dari definisi sederhana ini, kita menjadi tahu bahwa sebagian besar masyarakat masih berkutat pada bagaimana mendapatkan uang, belum memikirkan tiga aspek lainnya. Apalagi, merekapun masih bersusah payah untuk mendapatkan uang yang hanya satu aspek tersebut. Maka kitapun menjadi tahu bahwa mengapa ada artis, olahragawan ataupun profesi lainnya yang pada masa kejayaannya kaya raya bisa jatuh miskin di hari tuanya karena ia baru mengerti tentang cara mendapatkan uang dan belum tahu dengan benar bagaimana cara mengelola, menyimpan dan menggunakannya.

\section{Dimensi Financial Literacy}

Financial literacy mencakup beberapa dimensi keuangan yang harus dikuasai. Chen dan Volpe (1998) menyebutkan beberapa dimensi financial literacy yang meliputi pengetahuan umum keuangan, tabungan dan pinjaman, asuransi, serta investasi.

a. Pengetahuan umum tentang keuangan

Menurut S.P Wagland dan S. Taylor (2009), pengetahuan tentang keuangan mencakup pengetahuan keuangan pribadi, yakni bagaimana mengatur pendapatan dan pengeluaran, serta memahami konsep dasar keuangan. Konsep dasar keuangan tersebut mencakup perhitungan tingkat bunga sederhana, bunga majemuk, pengaruh inflasi, opportunity cost, nilai waktu uang, likuiditas suatu aset, dan lain-lain. 
b. Tabungan dan pinjaman

Menurut Garman dan Forgue (2010:376), tabungan adalah akumulasi dana berlebih yang diperoleh dengan sengaja mengkonsumsi lebih sedikit dari pendapatan. Dalam pemilihan tabungan, ada enam faktor yang perlu dipertimbangkan (Kapoor, et al., 2004:147), yaitu:

1) Tingkat pengembalian (persentase kenaikan tabungan),

2) inflasi (perlu dipertimbangkan dengan tingkat pengembalian karena dapat mengurangi daya beli),

3) pertimbangan pajak,

4) likuiditas (kemudahan dalam menarik dana jangka pendek tanpa kerugian atau dibebani fee),

5) keamanan (ada tidaknya proteksi terhadap kehilangan uang jika bank mengalami kesulitan keuangan, dan

6) pembatasan-pembatasan dan fee (penundaan atas pembayaran bunga yang dimasukkan dalam rekening dan pembebanan fee suatu transaksi tertentu untuk penarikan deposito).

c. Asuransi

Menurut Mehr dan Cammack (1980:16), asuransi merupakan suatu alat untuk mengurangi risiko keuangan, dengan cara pengumpulan unit-unit eksposur (exposure) dalam jumlah yang memadai, untuk membuat agar kerugian individu dapat diperkirakan. Kemudian, kerugian yang dapat diramalkan itu dipikul merata oleh mereka yang tergabung.

d. Investasi

Menurut Garman dan Forgue (2010:376), investasi adalah menyimpan atau menempatkan uang agar bisa bekerja sehingga dapat menghasilkan uang yang lebih banyak. Cara yang sering digunakan seseorang dalam berinvestasi yakni dengan meletakkan uang ke dalam surat berharga termasuk saham, obligasi dan reksa 


\section{JURNAL NOMINAL / VOLUME VI NOMOR 1 / TAHUN 2017}

dana, atau dengan membeli real estate.

\section{Mengelola Keuangan Pribadi}

Manajemen keuangan pribadi adalah seni dan ilmu mengelola sumber daya (money) dari unit individual / rumah tangga (Gitman 2002). Dalam proses pengelolaan tersebut, maka tidak mudah untuk mengaplikasikannya karena terdapat beberapa langkah sistematis yang harus diikuti. Namun dengan mengetahui manajemen keuangan pribadi, merupakan langkah awal untuk aplikasi yang tepat ketika mengelola uang pribadi. Hal ini didasari alasan bahwa segala sesuatu diawali dari kepala. Maksudnya adalah berpikir dahulu baru bertindak.

Pengelolaan keuangan pribadi juga menunut adanya pola hidup yang memiliki prioritas. Nalarnya adalah kekuatan dari prioritas (the power of priority) berpengaruh juga pada tingkat kedisiplinan seseorang ketika mengelola uangnnya (Benson 2004). Membahas tentang kedisiplinan yang merupakan kesadaran diri untuk mematuhi aturan serta kemampuan diri untuk menyesuaikan dirinya dengan perubahan, maka secara eksplisit telah menyentuh kontrol diri (self control). Hal ini berpijak pada alasan bahwa sukses atau tidaknya seseorang juga salah satunya turut dipengaruhi oleh Kontrol diri (Tangney, Baumeister \& Boone 2004).

Menurut Warsono (2010), mengelola keuangan pribadi dapat dilihat dari empat ranah yaitu:

1. Penggunaan dana. Dari mana pun sumber dana yang dimiliki, yang menjadi persoalan adalah bagaimana cara mengalokasikan dana (penggunaan dana) tersebut untuk memenuhi kebutuhan secara tepat. Pengalokasian dana haruslah berdasarkan prioritas. Skala prioritas dibuat berdasarkan kebutuhan yang anda perlukan, namun harus memperhatikan presentase sehingga penggunaan dana tidak habis digunakan untuk konsumsi sehari-hari saja. Presentasi pengalokasian dana yakni $70 \%$ dapat digunakan untuk pemenuhan konsumsi sehari-hari, $20 \%$ untuk ditabung, dan 10\% investasi. Karena $70 \%$ digunakan untuk konsumsi sehari-hari, maka diperlukan ketelitian dalam menghitung kebutuhan pribadi dalam keseharian, seperti makan, minum, rekreasi, kos, dan lainnya yang membantu anda pada tujuan pribadi. $70 \%$ ini haruslah tepat dan tidak berlebihan. $20 \%$ yang ditabung berguna untuk kebutuhan mendesak ataupun jika tidak digunakan, suatu saat dapat dipakai sebagai modal investasi. 10\% yang digunakan untuk investasi dapat direncanakan dengan matang, sehingga investasi tersebut dapat mendatangkan keuntungan dimasa mendatang. Memang sangat kecil presentase untuk investasi, dikarenakan kebutuhan investasi bukanlah sesuatu yang utama dalam pengelolaan keuangan pribadi. $10 \%$ 
tersebut tidaklah langsung diinvestasikan jika anda memiliki rencana bisnis yang besar, namun dapat ditabung dulu sebagai tabungan modal investasi. Perlu diingat, bahwa untuk berinvestasi dibutuhkan perencanaan yang matang.

2. Penentuan sumber dana. Seseorang harus mampu mengetahui dan menentukan sumber dana. Sumber-sumber dana dapat berasal dari orang tua, donatur maupun beasiswa. Selain itu seseorang juga dapat menentukan sumber dananya sendiri. Sumber dana dapat juga diciptakan dari berbagai usaha. Dengan mampu menentukan sumber dana, maka seseorang mengetahui dan mencari sumber dana alternatif lain sebagai sumber pemasukan keuangan untuk dikelola.

3. Manajemen resiko. Selanjutnya seseorang juga haruslah memiliki proteksi yang baik untuk mengantisipasi kejadian-kejadian yang tidak tertuga. Kejadiankejadian tidak terduga itu seperti sakit, kebutuhan mendesak dan lainnya. Hal yang sering dilakukan dalam melakukan proteksi tersebut adalah dengan mengikuti asuransi. Yang dimaksud dengan manajemen resiko adalah pengelolaan terhadap kemungkinan-kemungkinan resiko yang akan dihadapi.

4. Perencanaan masa depan. Masa depan merupakan hal yang akan dituju oleh setiap orang, untuk itu dibutuhkan suatu rencana yang matang dalam keuangan dalam menyongsong saat tersebut. Dengan merencanakan masa depan, maka anda juga menganalisa kebutuhankebutuhan dimasa depan, sehingga anda dapat menyiapkan investasi dari saat ini.
Selain empat ranah diatas, Senduk (2004) mengatakan bahwa manajemen keuangan pribadi meliputi keputusan tentang :

1. Membeli dan memiliki sebanyak mungkin harta produktif - Tentukan harta produktif yang yang ingin anda miliki. Harta produktif ini merupakan harta yang dapat menekan pengeluaran besar anda dalam kebutuhan sehari-hari. Seperti, jika anda mahasiswa maka memiliki komputer dan printer dapat mengurangi pengeluaran print dirental, dan lainnya. Harta produktif ini harus anda upayakan untuk miliki dengan cara membeli pada saat anda mendapatkan uang. Prioritaskan harta-harta produktif yang benar-benar mendukung aktivitas anda.

2. Mengatur

pengeluaran anda. Atur pengeluaran anda dan jangan sampai anda mengalami defisit. Usahakan dalam pengaturan pengeluaran anda, sudah dipastikan pos-pos pengeluaran tetap sudah terakomodir. Pelajari dan biasakanlah diri anda untuk mengeluarkan uang secara bijak dan tidak boros.

3. Berhati-hati

dengan

hutang. Anda harus mengetahui kapan saat yang tepat untuk berhutang, dan kapan saat yang tidak tepat tidak untuk berhutang. Banyak perusahaan dapat memanfaatkan hutang di bank sebagai modal usaha. Pada manajemen keuangan pribadi, jika anda mengalami defisit dan memaksa anda untuk berhutang, maka usahakanlah hutang tersebut tidak terlalu besar, dan mengganggu keuangan anda secara keseluruhan pada saat pengembalian hutang tersebut.

4. Sisihkan untuk masa depan. Rencanakan masa depan 


\section{JURNAL NOMINAL / VOLUME VI NOMOR 1 / TAHUN 2017}

anda secara sistematis. Karena dengan merencanakannya, anda dapat menyisihkan pemasukan anda sebagian untuk diinvestasikan bagi masa depan. Dengan membantu melakukan investasi masa depan dalam pengelolaan keuangan, maka anda mengurangi resiko untuk bergerak jauh dari masa depan yang anda inginkan.

5. Memiliki proteksi. Milikilah asuransi untuk melindungi anda dari berbagai bentuk resiko yang kemungkinan dapat terjadi. Jika anda belum memiliki penghasilan yang tetap, maka anda dapat membuka rekening tabungan dan menyisihkan uang anda sedikit dari pemasukan untuk ditabung sebagai anggaran proteksi pada resiko yang tidak anda harapkan.

Menurut Norma Yulianti dan Meliza Silvy (2013), dalam melakukan pengelolaan keuangan haruslah ada perencanaan keuangan untuk mencapai tujuan, baik tujuan jangka pendek maupun jangka panjang. Media pencapaian tujuan tersebut dapat melalui tabungan, investasi, atau pengalokasian dana. Dengan pengelolaan keuangan yang baik, maka tidak akan terjebak pada perilaku berkeinginan yang tidak terbatas. Parrota dan Johnson (1998) menyatakan bahwa manajemen keuangan pribadi dapat diartikan sebagai proses perencanaan, implementasi dan evaluasi keuangan yang dilakukan oleh individu ataupun keluarga, yang diharapkan individu ataupun rumah tangga akan mampu menciptakan kekayaan yang dibutuhkan untuk memenuhi kebutuhan saat ini maupun dimasa yang akan datang.

Pengelolaan keuangan yang baik diukur dengan lima komponen dari kemampuan seseorang dalam menganggarkan, menghemat uang, dan mengatur pengeluaran (Perry dan Morris, 2005). Lima komponen tersebut terdiri dari mampu membelanjakan uang seperlunya, membayar kewajiban bulanan tepat waktu, merencanakan keuangan untuk keperluan masa depan, menabung, dan menyisihkan dana untuk diri sendiri maupun keluarga. Dari kelima komponen tersebut, pengaruh yang paling besar terjadi pada mengatur pengeatur pengeluaran. Pengeluaran yang terjadi dalam rumah tangga cukup besar terjadi pada sektor non makanan yang meliputi biaya pendidikan, biaya listrik, telepon, asuransi, kesehatan dan lain sebagainya. Biaya pendidikan merupakan prioritas guna memenuhi pendidikan dan pembentukan masa depan bagi anak.

Pengelolaan keuangan pribadi juga ditentukan oleh pengetahuan yang dimiliki oleh setiap individu. Cummins (2009) mengungkapkan bahwa kemampuan seseorang untuk mengelola keuangan menjadi salah satu faktor penting untuk mencapai sukses dalam hidup, sehingga pengetahuan akan 


\section{JURNAL NOMINAL / VOLUME VI NOMOR 1 / TAHUN 2017}

pengelolaan keuangan yang baik dan benar menjadi penting bagi anggota masyarakat khususnya individu. Penelitian yang dilakukan oleh Ida (2010) menyatakan pengetahuan keuangan yang dimiliki oleh seseorang berpengaruh terhadap pengelolaan keuangan. Hal yang sama juga disampaikan dalam penelitian Andrew (2014) yang menyatakan bahwa terdapat hubungan yang signifikan antara pengetahuan keuangan dengan perilaku keuangan dimana semakin tinggi pengetahuan keuangan seseorang yang dimiliki akan cenderung lebih bijak dalam pengelolaan keuangannya.

\section{Perencanaan Keuangan}

Senduk (2000) mendefinisikan perencanaan keuangan adalah proses merencanakan tujuan-tujuan keuangan jangka pendek maupun jangka panjang (Yohnson, 2004). Wibawa (2003) mengungkapkan manfaat perencanaan keuangan tersebut yang pertama perencanaan keuangan tidak menjanjikan orang menjadi kaya mendadak, akan tetapi lebih pada pendisiplinan langkah untuk mengendalikan diri dan menyediakan kondisi finansial masa depan terbaik bagi diri sendiri dan keluarga secara efisien dan efektif sesuai dengan kemampuan finansial saat ini, yang kedua jaminan keuangan yang aman (secure) dan yang ketiga perencanaan keuangan keluarga akan membantu secara efisien dan efektif meraih citacita finansial.

Sembel, et al (2003) dalam Rita dan Santoso menjelaskanbeberapa alasan mengapa perencanaan keuangan perlu dilakukan oleh individu maupun keluarga, yaitu untuk melindungi diri sendiri dan keluarga dari berbagai risiko yang berdampak secara finansial ( seperti kecelakaan, penyakit, kematian, dan tuntutan hukum), mengurangi hutanghutang pribadi / keluarga, membiayai kehidupan saat tidak lagi berada dalam rentang usia produktif, ini berkaitan dengan naiknya tingkat ekspektasi hidup rata-rata manusia di suatu negara, membayar biaya-biaya yang diperlukan untuk membesarkan anak, menyediakan biaya pendidikan anak sampai ke perguruan tinggi, membayar biaya pernikahan, membeli kendaraan, membeli rumah, mampu menentukan masa pensiun dengan gaya hidup yang kita inginkan, membayar biaya-biaya perawatan yang bersifat jangka panjang, dan mewariskan kesejahteraan kepada generasi berikutnya. 


\section{JURNAL NOMINAL / VOLUME VI NOMOR 1 / TAHUN 2017}

\section{PENUTUP}

Dalam menjalani kehidupan, kebahagiaan tidak selalu harus dicapai melalui nilai kekayaan yang besar, karier yang sangat tinggi, dan sebagainya, tetapi sebenarnya kebahagiaan dapat dicapai melalui penerimaan atas keadaan yang ada. Dengan memahami dan melaksanakan manajemen keuangan pribadi, maka kita telah mengetahui tujuan tertinggi dan bagaimana mencapainya. Pengelolaan keuangan pribadi sangat membantu untuk menjalani aktivitas secara terencana secara finansial.

Literasi keuangan adalah kemampuan (kecakapan) seseorangan dalam membuat keputusan yang efektif berhubungan dengan keuangannya. Literasi keuangan membantu individu terhindar dari masalah keuangan terutama yang terjadi akibat kesalahan pengelolaan keuangan. Literasi keuangan dalam bentuk pemahaman terhadap semua aspek keuangan pribadi bukan ditujukan untuk mempersulit atau mengekang orang dalam menikmati hidup, tetapi justru dengan literasi keuangan, individu atau keluarga dapat menikmati hidup dengan mendayagunakan sumberdaya keuangannya dengan tepat dalam rangka mencapai tujuan keuangan pribadinya.
Pentingnya literasi keuangan bagi individu bukan sekedar sebagai ilmu pengetahuan ataupun teori saja, tetapi diharapkan dapat membuat individu lebih bijaksana dan pandai dalam mengelola aset yang dimilikinya sehingga dapat memberikan timbalbalik yang bermanfaat dalam menyokong keuangan individu baik dalam jangka pendek maupun jangka panjang.

\section{DAFTAR PUSTAKA}

Andjani, Sari. 1991. Efektifitas Teknik Kontrol Diri pada Pengendalian Kemarahan. Jurnal Psikologi. Tahun ke XVIII Nomor 1.

Andrew, V. dan Linawati, N. 2014. "Hubungan Faktor Demografi dan Pengetahuan Keuangan Dengan Perilaku Keuangan Karyawan Swasta di Surabaya". Finesta. Vol. 2 (2) : pp 35-39.

Aribawa, Dwitya. 2016. Pengaruh Literasi Keuangan terhadap Kinerja dan Keberlangsungan UMKM di Jawa Tengah. Jurnal Siasat Bisnis Vol. 20 No.1, 1-13.

Chen, H \& Volpe, RP. 1998. "An Analysis of Personal Financial Literacy among College Students." Financial Services Review, 7(2), 107-128.

Conceptualising Financial Literacy by. Carolynne L J Mason and Richard M S Wilson. Business School Research Series. Paper 2000: 7. ISBN 1859011683. 
Conceptualising Financial Literacy by. Carolynne L J Mason and Richard $M S$ Wilson. Business School Research Series. Paper 2000: 7. ISBN 1859011683.

Cummins M., Haskel J. H., \& Jenkins S. 2009. "Financial Attitudes And Spanding Habits Of University Fresmen". Journal Of Economics And Economic Education Research. Vol. 10 (1) : pp. 3-6.

Dewi, MK., Khotimah, S., dan Puspasari, N. 2015. Telaah financial Literasi mahasiswa FEB Universitas Jenderal Soedirman: Suatu Implikasi Pembelajaran di Perguruan Tinggi.

Gitman, L. 2004. Principle of Finance, (11th ed).(2002). Prentice Hall, New Jersey

Hailwood, DWAK 2007, 'Financial Literacy and its Role in Promoting a Sound Financial System', Reserve Bank of New Zealand, Vol 70, No. 2.

L. Giltman. 2004. "Princile of finance". (11th ed) 2002. Prectice Hall : New Jersey

Lusardi, A., \& Mitchell, O. S. (2007). Baby Boomer Retirement Security: The Roles of Planning, Financial Literacy, and Housing Wealth. Journal of Monetary Economics, 54, 205-224.

Lusardi, A dan O.S. Mitchell. 2014. The Economic Importance of Financial Literacy: Theory and Evidence. Journal of Economic Literature 2014, 52(1), 5-44.

Margaretha, Farah dan Pambudhi, RA. 2015. Tingkat Literasi Keuangan pada mahasiswa S1 Fakultas Ekonomi. JMK. Vol 17 No. 1. Hal 76-85.
Mendari, AS dan Kewal, SS. 2013. Tingkat Literasi Keuangan di Kalangan Mahasiswa STIE MUSI. Jurnal Economia. Vol. 9 No. 2. Hal 130-140.

MZ. Zahriyan. " Pengaruh Literasi Keuangan dan Sikap terhadap Uang Pada Perilaku Pengelolaan Keuangan Keluarga eprints.perbanas.ac.id/312/1/ART IKEL\%2OILMIAH.pdf

Navickas, M ,Tadas G dan Emilia K, 2013, Influence on Financial Literacy on Management of Personal Finances in A Young Households, Lithuania .

Norma Yulianti dan Meliza Silvy. 2013. "Sikap Pengelola Keuangan dan Perilaku Perencanaan Investasi Keluarga di Surabaya". Journal of Business and Banking. Volume 3. No 1. Hal 57-68.

OECD INFE. 2012. PISA 2012 Literacy assessment framework. [Report Paper]

Otoritas Jasa Keuangan. 2013. OJK Perkuat Upaya Inklusi dan Perluasan Akses Keuangan Melalui Literasi Keuangan. Majalah OJK Edisi November. (Retrifed from: http://sikapiuangmu.ojk.go.id/pub lic/content/files/Majalah-OJK2.pdf.).

Parrota, J. L. \& Johnson, P. J. 1998. The Impact Of Financial Attitudes And Knowledge On Financial Management And Satisfaction Of Recently Married Individuals. Association for Financial Counseling and Planning Education.

Perry, VG \& Morris, M.D. 2015. "Who Is In Control? The Role and Income In Explaining Consumer 
Financial Behavior". The Journal of Consumer Affairs, Vol.39, No 2, pp 299-313.

Rita, MR dan Santoso, B. 2015. Literasi Keuangan dan Perencanaan Keuangan pada Dana Pendidikan Anak. Jurnal Ekonomi. Vol XX. No. 012. Hal 212-227.

Rohrke, A, \& Robinson, L 2000, 'Guide to Financial Literacy Resources', Journal of Financial Literacy.

S. Senduk. 2004, "Siapa Bilang Jadi

Karyawan Ngak Bisa Kaya; Lima Kiat Praktis Mengelola Gaji Agar Bisa Kaya", Elex Media Komputindo : Jakarta,

Tangney, J. P, Baumeister, r. f. \& Boone, A. L. 2004. High Self-Control Predicts Good Adjustment, Less Pathology, Better Grades, and Interpersonal Success. Journal of Personality 72:2, April 2004.

Warsono. 2010. "Prinsip-Prinsip dan Praktik keuangan Pribadi". Journal of Science, volume 13 Nomor 2 Juli-Desember 2010

Zahroh, Fatimatus. 2014. Menguji Tingkat Pengetahuan keuangan, Sikap Keuangan Pribadi, dan Perilaku Keuangan Pribadi Mahasiswa Jurusan Manajemen Fakultas Ekonomika dan Bisnis Semester 3 dan Semester 7. Skripsi. FEB Undip. 